\title{
FOREIGN TRADE AS A TOOL TO STRENGTHEN THE EU'S COMPETITIVENESS AGAINST CHINA (A CASE OF THE SERVICE SECTOR)*
}

\section{Peter Baláža , Michaela Královičováa , Dušan Steinhausera}

\begin{abstract}
The paper analyses some aspects of EU-China trade relations. Correlation analysis was applied to quantify the extent of the influence of the foreign trade with China on the overall foreign trade of the five members of the EU that have the largest foreign trade with China. Given the ongoing trade deficits of the EU with China, we decided to apply the Trade Complementarity Index (TCI) to determine the extent of their trade complementarity. Our initial hypothesis that the economies are highly complementary was rejected. We thus decided to apply the TCI to the EU's trade relations with the US. For the US, the TCI confirmed the existence of high trade complementarity. This implies that the EU can strengthen its negotiating power with China by increasing its trade diversification. These conclusions were also supported by our econometric model. A thorough analysis of EUChina trade relations also revealed the growth potential of the trade in services, which is gaining its momentum given the turbulences in global trade. The paper suggests that the EU needs to strengthen its trade relations with its "natural trade partners" instead of concentrating on China. The paper's focus on trade in services is a major contribution as it has so far been neglected in the economic literature.
\end{abstract}

Keywords: Competitiveness, China, EU, foreign trade, service sector

JEL Classification: F13, F40, F50, L80, O11, O14

a University of Economics Bratislava, Bratislava, Slovakia

Email: peter.balaz@euba.sk,mk.kralovicova@gmail.com,dusan.steinhauser@euba.sk

* The paper is part of VEGA project. No. 1/0897/17 “The Importance of European Energy Union

Project for its Strategic Interests in the Context of the Enhancement of Competitiveness of Slovakia".

This article is based primarily on the dissertation Královičová (2018), which was elaborated under the leadership of prof. Ing. Petr Baláž, PhD. deceased in 2019. Thank you and rest in peace! 


\section{Introduction}

China's influence in the world economy is steadily rising and its spheres of activity and interest are continuing to expand (Koopman et al., 2011). Since 2009, China has been maintaining its position as the world's largest exporter of goods (Baláž et al., 2012). In 2014, it even surpassed the US in the cumulative volume of imports and exports of goods, thus becoming the world's largest trading nation. At present, it is already the world's largest economy on the basis of GDP measured in purchasing power parity. In 2016, China's share of the world's population was nearly $20 \%$, with its share of world GDP being $14.8 \%$. In the same year, China also accounted for 9.5\% of all the world's imports, and its share of the world's exports was 10.6\% (World Bank, 2018). The International Monetary Fund (IMF) predicts that China's contribution to global GDP growth will reach as high as 35\% in 2018 .

China's economic potential has not yet been fully achieved, and further strengthening of its leading position in the global economy can be expected. In order to maintain its own competitiveness, the EU will need to learn to respond and effectively adapt to the changes brought by China into the world economic environment. In this paper, we try to identify the main development trends of China and their implications not only for the competitiveness of the $\mathrm{EU}$ as a whole but also for its individual member states. We try to highlight the potential for the further development of mutual trade relations.

The official cooperation between the EU (known as the EEC - European Economic Community at that time) and China began to intensify in 1975 and a strategic partnership was established in 2003. The years 2003 and 2004 were the period of the fastest development of mutual cooperation between these two partners. The period from 2005 to 2008 marked a partial cooling of the relations, which was partly caused by the deteriorating global economic conditions. As a consequence, the EU's strategies and documents have increasingly defined EU-China relations as those of "competitors and partners", which is in sharp contrast to their previous definition as "strategic partners". In 2009, EU-China relations were partially normalized; however, they continue to be troubled by short-term conflicts, misunderstandings and mistrust (Zhou et al., 2017).

The EU and China regularly impose various unilateral anti-dumping and anti-subsidy measures on each other. In December 2016, the bilateral relations between the EU and China deteriorated as a result of the EU's refusal to grant "market economy status" to China (Fojtíková, 2017). Member countries of the EU are worried about losing the ability to effectively prevent the "flood" of cheap goods that granting the status of a market economy to China would most likely cause. Disputes between the partners concern numerous areas, such as the EU's embargo on arms exports to China, visits of the Dalai Lama on the European continent, or the EU's criticism of human rights violations in China 
(European Commission, 2018a). The OBOR initiative ${ }^{1}$, China's individual summits with selected member countries of the EU (e.g., Germany, the UK and Poland) as well as the $16+1$ initiative 2 , by which China ignores the EU's boundaries, suggest that in order to obtain an understanding of the true intentions of the Chinese government, it is necessary to abstain from the position of the $\mathrm{EU}$ as the dominant player in mutual negotiations between China and the EU (Baláž and Královičová, 2017).

\section{Methodology}

The paper focuses on identifying to what extent declines in Chinese exports and imports affect the development of the foreign trade of the selected EU member countries. Given the prevailing asymmetry between individual EU member countries in their trade relations with China, we considered it necessary to analyse the impact of China's foreign trade separately for individual EU member countries. We believe that only such a view will allow us to obtain a real picture of the significance, current state and prospects for further development of the trade relations of these economies, and consequently, their competitiveness. The significance of each country's foreign trade share with China was assessed in terms of its total foreign trade. This approach allowed us to better identify those EU countries whose competitiveness is most dependent on the developmental trends of China's foreign trade policy. In order to achieve our aim, we tried to conduct our analysis in a way that would allow its continuation in the future. By doing so, we created a foundation for further research. The main components serving this purpose are the Trade Complementarity Index (TCI), correlation analysis and a simplified version of the gravity model. We decided for a simplified version of the gravity model due to the complexity of the assessed relations (e.g., the relation between the EU, which has 28 member states, and China). Our simplified model uses a variable of exports of transport services to partner countries. ${ }^{3}$

The potential of the EU-China foreign trade was determined by the TCI. The TCI measures trade complementarity between two selected countries. Drysdale and Garnaut (1982) applied this index to determine the scope of mutual trade between two countries, its commodity structure, and the impact of bilateral trade relations on the countries' prosperity. The TCI can determine the intensity and the extent to which the export of one

1 The New Silk Road initiative, also known also as One Belt One Road (OBOR), is a global project of the Chinese government, which aims to build and renovate infrastructure and facilitate global trade. Currently, over 70 countries participate in the initiative.

2 The $16+1$ initiative is a platform facilitating the dialogue between China and 16 countries of Central and Eastern Europe.

3 The authors considered using additional econometric methods. Nevertheless, this approach was abandoned due to lack of relevant data and inconsistencies among data gathered from different databases. 
country overlaps with imports from another country of the world economy (Finger and Kreinin, 1979). It examines the impact of the commodity structure of the two trade partners (countries) on the intensity of their foreign trade, which makes it possible to identify the untapped trade potential between the world's economies. The import and export values for the assessed countries are added to the TCI formula as aggregate quantities for individual commodity groups within their Standardized International Trade Classification (SITC) classes. A high degree of the resulting level of trade complementarity implies greater prospects of developing bilateral trade between the countries. The formula calculated in the paper was as follows:

$$
c^{i j}=100\left[1-\sum \frac{\left|m_{k}^{i}-x_{k}^{j}\right|}{2}\right],
$$

where $c^{i j}$ is the TCI, $x_{k}^{j}$ represents the share of the product $k$ on the total exports of the country $j$, whereas $m_{k}^{j}$ represents the share of the product $k$ on the total imports of the country $i$.

If the resulting TCI values are approaching or equal 100, it means that there is a strong trade complementarity between the assessed countries, meaning that these countries are ideal trade partners. If the TCI values approach 0 , it means that there is a relatively weak trade complementarity between the two countries. Provided that the TCI values equal 0 , the countries are ideal trade competitors, with no trade exchanges between them.

Numerous economists have been devoting their long-term research to the TCI. They have been trying to incorporate other variables into the original formula that could explain the impact of trade barriers and other dynamic factors on the structure and intensity of bilateral trade relations between countries. At present, however, there is no consensus about a uniform structure of the formula for this index. We decided to apply the most common form of the formula. Despite the limitations presented, we consider this index to be a sufficient theoretical basis for our research as we believe that the three global economies under review (the EU, China and the US) are similarly geographically distanced from each other and there is neither an EU-China free trade agreement nor a free trade agreement between the EU and the US, which suggests that the resulting TCI values should not be distorted due to the presented limitations. When assessing the foreign trade dependence of the selected EU member countries on China and its statistical significance, the correlation analysis was applied. The two quantitative variables selected were the total foreign trade balance of the selected EU member countries and their foreign trade balances with China. The value of the correlation coefficient is between -1 and 1 . The value of -1 indicates a perfect downhill (negative) linear relationship, 1 means a perfect uphill (positive) linear relationship, and 0 indicates the independence of the observed variables (Christmann and Badgett, 2009). 
Our statistical findings were verified by an econometric model inspired by the gravity model (Grančay, 2013). The gravity model is based on the hypothesis that economies have a higher trade intensity the bigger and geographically closer they are. Our equation revealed a mutual relationship between the dependent variable Export_EU5 (M. Grančay uses trade turnover as the sum of exports and imports), which is the exports of the five EU economies of Germany, Italy, the Netherlands, the UK and France to partner countries, and the independent variables, which are the sum of transportation services exports of the five countries (Transport_EU5), GDP per capita (current \$), and a dummy variable showing membership in the EU, which is 1 for members and 0 for non-members (EU_m). The dummy variable was added to the model because membership in an integration grouping not only stimulates mutual trade between its members but also indirectly quantifies foreign trade barriers. Because neither China nor the US have a free trade agreement with the EU, we decided to omit the effect of free trade agreements in our analysis. The sum of transportation services exports of the EU5 substitutes for the traditionally used variable of geographical distance. M. Grančay (2013), e.g., used the distance between the capital cities as a variable. Nevertheless, such an approach would be difficult to employ as our research concentrates on a group of five economies instead of one country. Our assumption is that these five economies export transportation services primarily to countries that are geographically close or offer easy access. This approach enabled us to indirectly estimate transportation costs, which are often omitted in gravity models. Our database was composed of data from UNCTAD (2018) for 2016 and we also included the estimated values. After data cleaning, we were left with 53 observations. The descriptive statistics (Pacáková et al., 2009) of the input data are shown in Table 1.

Table 1: Descriptive statistics

\begin{tabular}{l|r|c|c|c}
\hline $\mathbf{N}=\mathbf{5 3}$ & Export_EU5 & Transport_EU5 & EU_m & GDP_pc \\
\hline Mean & $37,251,454.43$ & $2,005.39$ & 0.43 & $26,322.68$ \\
\hline Kurtosis & 9.41 & 28.29 & -2.00 & 1.06 \\
\hline Skewness & 2.83 & 4.82 & 0.27 & 1.22 \\
\hline Minimum & $1,024,934.88$ & 104.31 & 0 & $1,706.46$ \\
\hline Maximum & $278,411,303.77$ & $22,700.60$ & 1 & $101,835.22$ \\
\hline Sum & $1,974,327,084.58$ & $106,285.79$ & 23.00 & $1,395,102.19$ \\
\hline
\end{tabular}

Source: Authors' calculations based on data from UNCTAD, 2018 
The econometric model was created in the Excel and Gretl software. The equation was interpreted with the help of economic literature (Lukáćik et al., 2011) and has the following form:

$$
\text { ln_Export_EU5 }=\mathrm{const}+\mathrm{b}_{1} * \ln \_ \text {Transport_EU5 }+\mathrm{b}_{3} * \ln \_\mathrm{GDP} \_\mathrm{pc}+\mathrm{b}_{2} * \text { EU_m, }
$$

where ln_Export_EU5 is the natural log of cumulative merchandise exports in thousands of $\$$ of the EU5; constant (const); ln_Transport_EU5 is the natural log of the EU5 transportation services exports in millions of $\$$; $\ln \_$GDP_pc is the natural log of the gross domestic product per capita in $\$$ of the 53 observed countries and EU_m points to membership in $\mathrm{EU}<0 ; 1>$. Regression coefficients are represented by $\mathrm{b}_{1}$ to $\mathrm{b}_{3}$.

\section{Results}

The research confirmed that the foreign trade between the EU and China shows a long-term trend to the EU's disadvantage. In the last decade, the EU did not manage to achieve an active foreign trade balance with China in any of the years. In trade in goods, the EU has been recording a passive balance for a long time. The EU was China's largest trade partner in 2016. Overall, China accounted for $14.9 \%$ of EU foreign trade in 2016. In the same year, China was the second most important trade partner of the EU, with the US being the leader. It held a share of $20.1 \%$ of total EU imports and $9.7 \%$ of total EU exports (Eurostat, 2017). In 2016, the EU-China trade turnover was $€ 514.7$ bln and the EU recorded a passive trade balance of $€ 137.5 \mathrm{bln}$. In trade in services with China, on the other hand, the EU recorded a trade turnover of $€ 67.9$ bln and had an active trade balance of $€ 8.8$ bln. However, the active trade balance in services represented only a fraction of the total mutual trade. Even the EU's long-term active trade balances in services with China do not have a significant impact on the outcome of the overall foreign trade between them. In 2016, the share of the trade turnover in services in the total EU-China foreign trade turnover was only $7.58 \%$ (European Commission, 2018a). The development of the mutual trade from the perspective of the EU can be seen in Figure 1.

Despite the significant media coverage of China's relations with individual EU countries, the intensity of foreign trade of most of these countries with China remains at a relatively low level. For imports, China was the most important trade partner in 2016 for only one EU member, Germany, with a share of $9.93 \%$ in its total imports. China reached a share higher than $10 \%$ of total imports in only two member countries, namely the Czech Republic and Poland (Eurostat, 2017). For exports, China's shares were even lower, with China not being ranked among the top three trade partners for any EU member country. In the case of Poland, Greece, Croatia, Lithuania and Slovenia, China did not even 
rank among the top twenty of their most important export partners. It should be stressed that Germany was the only EU member country that ranked among the ten most important trade partners of China. The analysis shows that despite efforts of political leaders and attention of the media, the trade between individual EU member countries and China is still only of a marginal significance for China.

Figure 1: EU-China foreign trade in goods between 2010 and 2016 (million €)

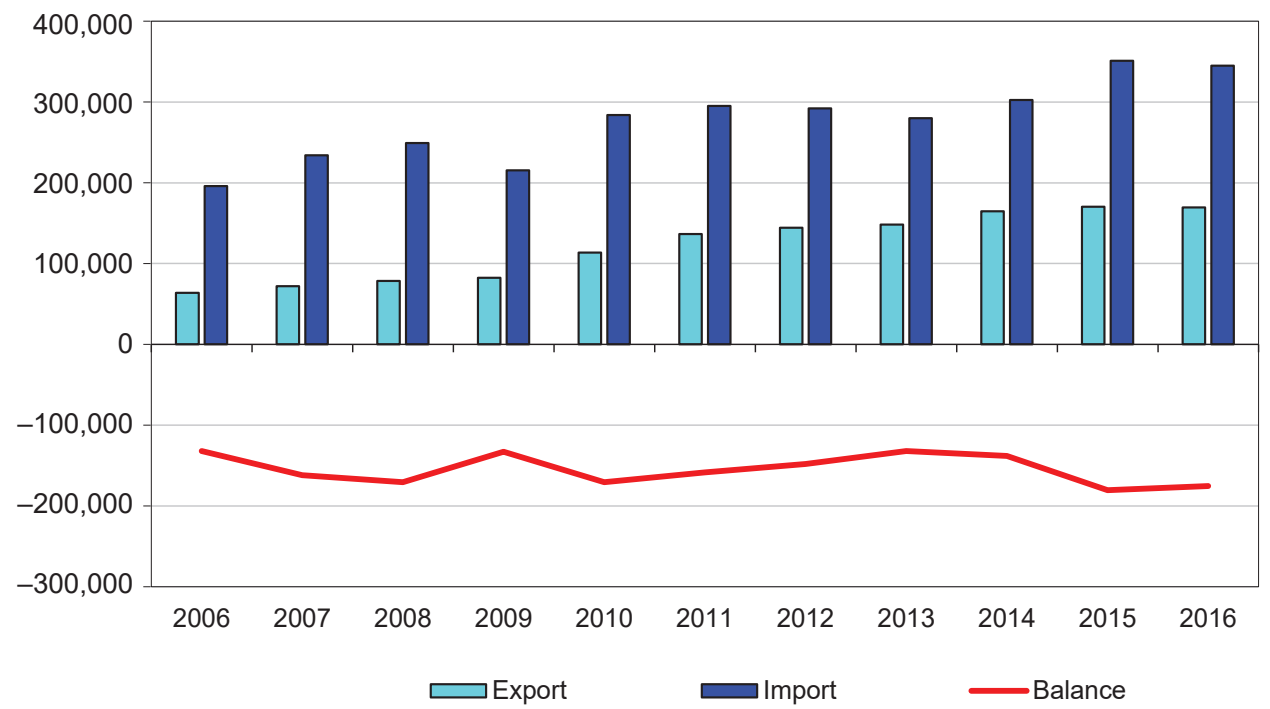

Source: Authors' calculations based on data from Eurostat, 2017

Germany, France, the UK, Italy and the Netherlands were China's most important trade partners in the EU for both exports and imports in 2016. Regarding China's imports, the combined share of these five countries was $9.69 \%$. The share of the same countries in China's exports was $10.95 \%$. These five countries together accounted for almost $70 \%$ of the total turnover of the EU with China (2016). The share of Germany alone, which has the largest volume of foreign trade with China of all EU member countries, was about $30 \%$ in 2016.

All 28 EU member countries have long-term passive foreign trade balances with China. This is also the case for the 5 countries with the largest volume of foreign trade with China among the members. Germany, the Netherlands and Italy recorded active balances of their total foreign trade in 2016, but their foreign trade balances with China were passive (Table 2). 
Table 2: Foreign trade between China and its top 5 EU trade partners (2016)

\begin{tabular}{l|c|c|c|c|c|c|c}
\hline Country & $\begin{array}{c}\text { Imports from } \\
\text { China } \\
\text { (thousand \$) }\end{array}$ & $\begin{array}{c}\text { China's } \\
\text { share } \\
\text { on import } \\
\text { (\%; rank) }\end{array}$ & $\begin{array}{c}\text { Exports } \\
\text { to China } \\
\text { (thousand \$) }\end{array}$ & $\begin{array}{c}\text { China's } \\
\text { share } \\
\text { on exports } \\
\text { (\%; rank) }\end{array}$ & $\begin{array}{c}\text { Passive } \\
\text { foreign trade } \\
\text { balance with } \\
\text { China }\end{array}$ & $\begin{array}{c}\text { Total foreign } \\
\text { trade balance } \\
\text { (thousand \$) }\end{array}$ & $\begin{array}{c}\text { Foreign } \\
\text { trade } \\
\text { turnover } \\
\text { with China } \\
\text { (thousand \$) }\end{array}$ \\
\hline Germany & $105,289,752.56$ & $9.93(1)$ & $85,350,435.97$ & $6.37(5)$ & $19,939,316.58$ & $280,080,028.94$ & $190,640,188.5$ \\
\hline the UK & $59,575,883.13$ & $9.36(2)$ & $18,142,280.19$ & $4.41(7)$ & $41,433,602.95$ & $-224,904,580.57$ & $77,718,163.32$ \\
\hline France & $51,032,597.79$ & $9.10(2)$ & $17,705,737.32$ & $3.62(7)$ & $33,326,860.47$ & $-71,669,790.26$ & $68,738,335.11$ \\
\hline $\begin{array}{l}\text { the Neth- } \\
\text { erlands }\end{array}$ & $35,846,315.63$ & $9.00(3)$ & $10,520,046.57$ & $2.36(9)$ & $25,326,269.06$ & $46,531,024.01$ & $46,366,362.2$ \\
\hline Italy & $30,194,170.63$ & $7.46(3)$ & $12,258,629.86$ & $2.66(9)$ & $17,935,540.77$ & $56,951,427.66$ & $42,452,800.49$ \\
\hline
\end{tabular}

Source: Authors' processing based on data from WITS, 2018

During the period from 2006 to 2016, the foreign trade balance of Germany recorded the biggest decline in 2009, in which Germany's trade surplus amounted to $\$ 189.48$ bln. In 2008, the total trade surplus of Germany was $\$ 261.93$ bln but its trade deficit with China was $\$ 37.45$ bln. This development was in contradiction with the development of Germany's overall trade balance. The development trajectory presented in Figure 2 shows that the foreign trade with China does not have a major impact on the overall trend of Germany's trade balance. This was also supported by the results of the correlation analysis, which did not show any statistically significant dependence. The correlation coefficient was 0.34 , which represents only a slight linear dependence. Further, this correlation coefficient was estimated at a low t-statistic (1.082).

While the total trade balance of the UK was experiencing significant fluctuations over the period from 2006 and 2016, its foreign trade balance with China was developing more proportionally. The UK has a long-term deficit of its total foreign trade and its foreign trade with China is also negative in the long run. The UK recorded the biggest trade deficit in 2016 (\$224.90 bln). Its trade deficit with China was the highest in 2011 (\$51.95 bln) A comparison of the trends of the two variables revealed, however, that there was no significant statistical dependence between their development (Figure 3 ). The correlation analysis revealed a linear dependence of 0.56 , which represents a moderate linear dependence. This means that the UK's foreign trade balance with China correlates more strongly with the overall trade balance of the UK, as is the case of Germany. However, the $t$-statistic of the correlation coefficient is not statistically significant. 
Figure 2: Development of total foreign trade balance of Germany and its foreign trade balance with China

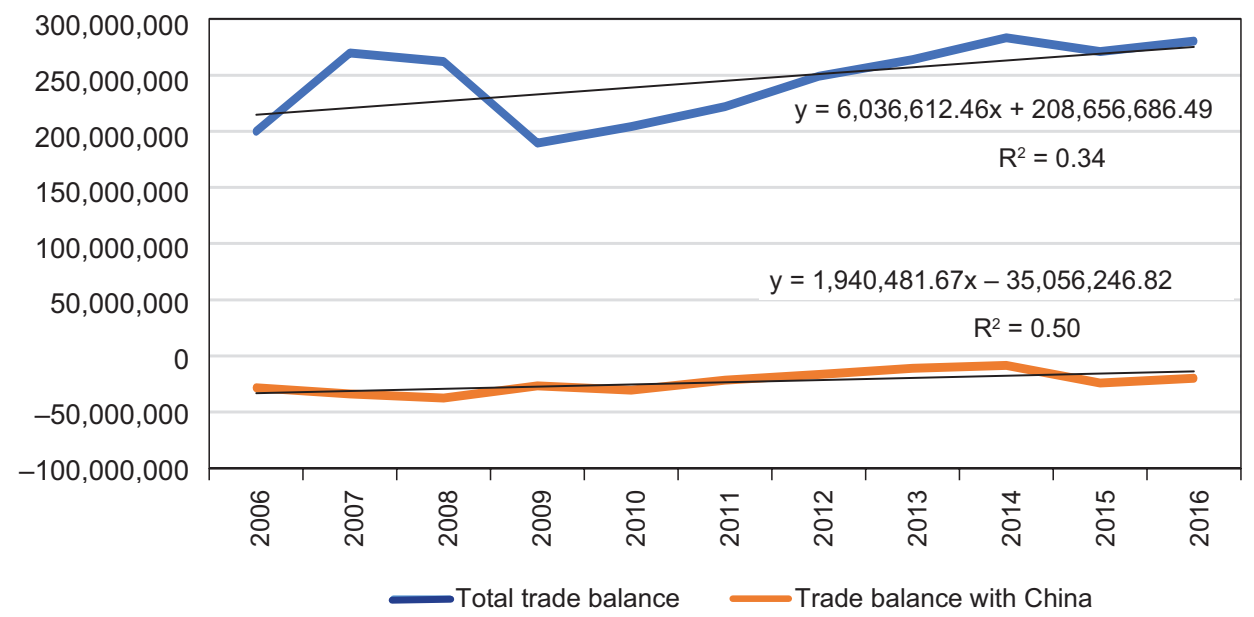

Source: Authors' calculations. Correlation analysis run in Gretl with data from WITS, 2018

Figure 3: Development of total foreign trade balance of the UK and its foreign trade balance with China

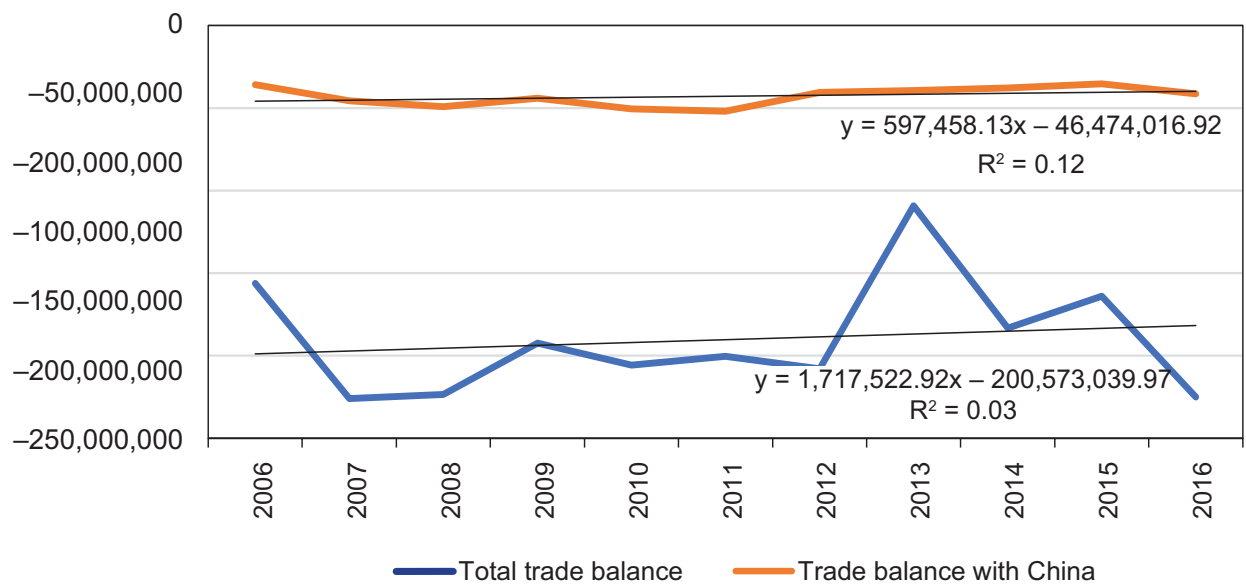

Source: Authors' calculations. Correlation analysis run in Gretl with data from WITS, 2018

In the assessed period, France recorded a passive trade balance every year. The country's trade deficit was the lowest in 2006, when it reached $\$ 50.89$ bln, and the highest in 2011, when it was $\$ 127.95$ bln. France's trade deficit with China also reached the lowest value in 2006 (\$19.95 bln), with the highest passive trade balance 
recorded in 2011 ( $\$ 38.69$ bln). The correlation coefficient was statistically significant based on the t-statistics. This situation is also evidenced by the value of the correlation coefficient value (0.82), which demonstrates a strong direct linear dependence. The result of the correlation analysis thus revealed that the trade balance with China has a significant impact on the balance of the total foreign trade of France (Figure 4).

Figure 4: Development of total foreign trade balance of France and its foreign trade balance with China

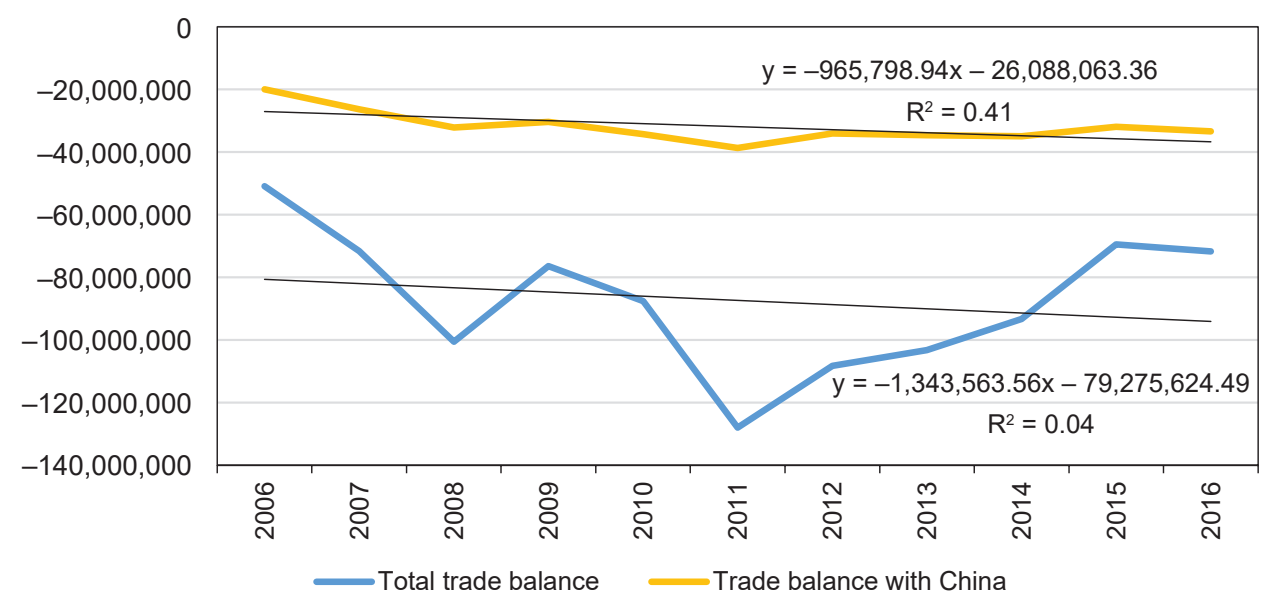

Source: Authors' calculations. Correlation analysis run in Gretl with data from WITS, 2018

In the period between 2006 and 2016, the Netherlands recorded an active balance of its total foreign trade annually. The lowest value was recorded in 2011 ( $\$ 37.74 \mathrm{bln}$ ), and the highest value was recorded in 2013 ( $\$ 65.08$ bln). With China, however, the Netherlands recorded a passive trade balance each year. The Netherlands' lowest passive trade balance with China was recorded in 2009 ( $\$ 24.20$ bln). The highest passive trade balance with China was recorded in 2014 ( $\$ 36.55$ bln). The correlation analysis revealed that there is a moderate indirect linear dependence between the variables. Thus, the development of the overall trade balance of the Netherlands is not subject to a significant impact of the development of the foreign trade balance of the Netherlands with China (Figure 5).

Between 2006 and 2011, Italy was recording passive trade balances annually. Its deficit was the highest in 2010 ( $\$ 40.14$ bln). Since 2012, Italy's foreign trade has been in surplus, with the highest active trade balance reaching $\$ 56.95$ bln in 2016. With China, Italy records negative trade balances annually. Italy had the lowest negative balance with 
China in 2006 ( $\$ 15.39$ bln). The highest trade deficit with China, on the other hand, was recorded by Italy in 2011 ( $\$ 27.27$ bln). For Italy, the correlation analysis did not reveal any statistically significant dependence between the development of its total trade balance and the development of its trade balance with China (Figure 6).

Figure 5: Development of total foreign trade balance of the Netherlands and its foreign trade balance with China

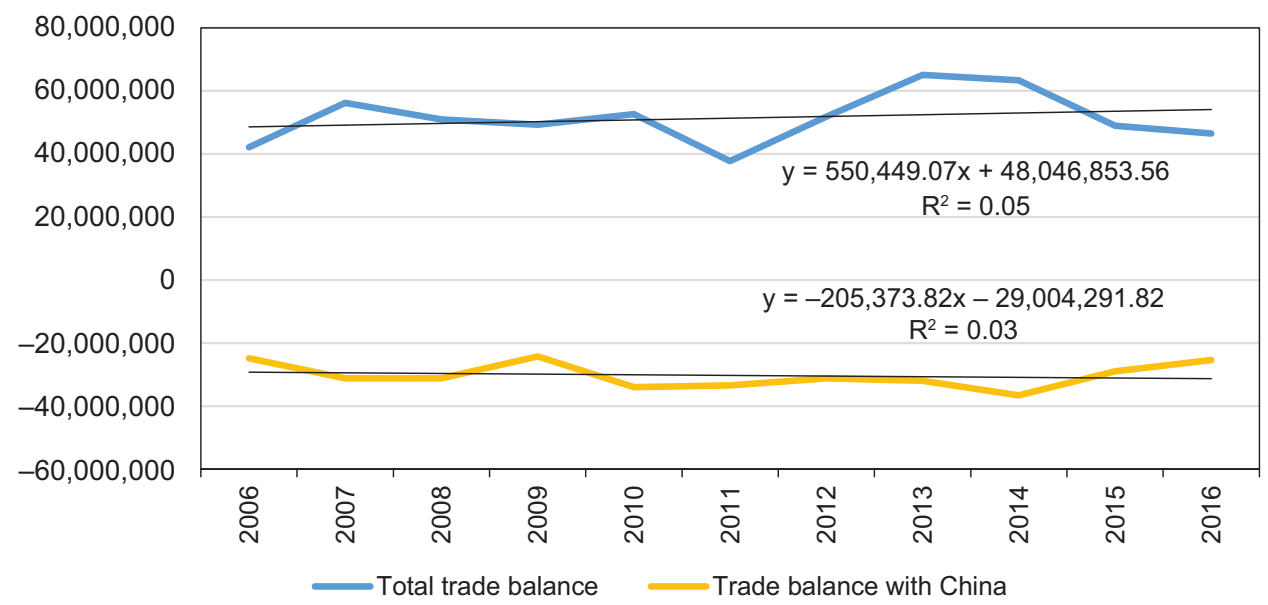

ource: Authors' calculations. Correlation analysis run in Gretl with data from WITS, 2018

Figure 6: Development of total foreign trade balance of Italy and its foreign trade balance with China

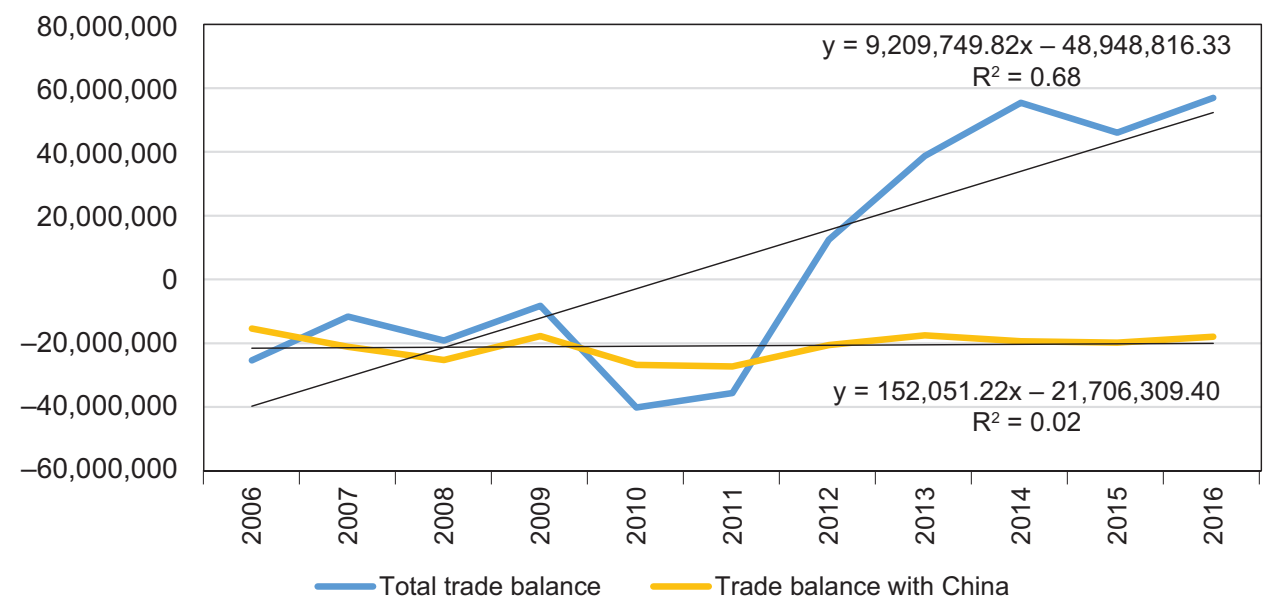

Source: Authors' calculations. Correlation analysis run in Gretl with data from WITS, 2018 
The correlation analysis of the foreign trade relations between China and the five EU countries with the largest foreign trade turnover with China revealed that there is no significant dependence between the total trade balance of four of the analysed member countries (Germany, the UK, the Netherlands and Italy) and their trade balance with China. The only exception is France, for which a strong direct statistical dependence was revealed between the variables. The correlation analysis revealed that the trade balances of the assessed countries maintain a relatively proportional trend of development, with none of the countries recording any substantial increase in its foreign trade dependency on China during the period under review. The analysis also revealed that China has a significant impact on the foreign trade balance only with France.

After running the correlation analyses, which revealed the relative independence of the development of the foreign trade of the selected member countries from the development of their trade with China, we worked with the hypothesis that the economies of the EU and China are complementary and tried to find out whether the EU-China interdependence has deepened further in the new millennium. To test this hypothesis, the $\mathrm{TCI}^{4}$ was calculated. An index value of 70 and above is considered to mean "high trade complementarity" in this paper.

\section{Figure 7: Development of trade complementarity between the EU and China}

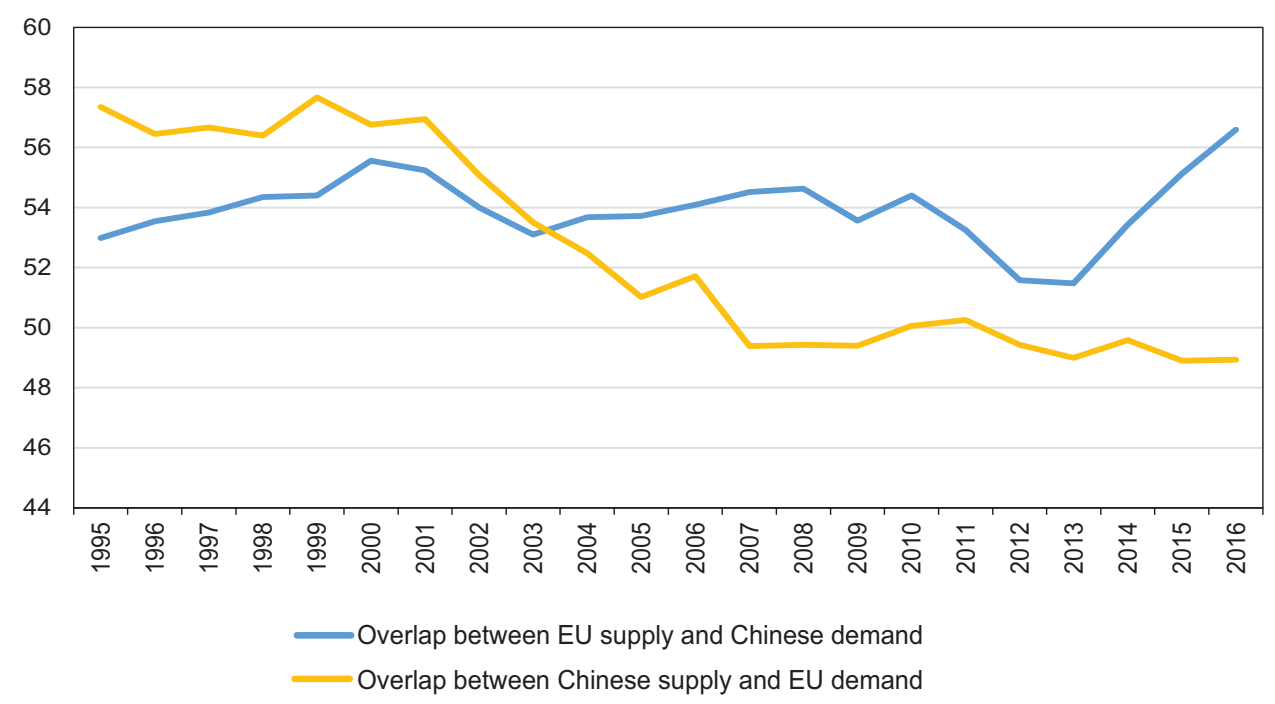

Source: Authors' calculations. The TCI was calculated based on data from UNCTAD, 2018

4 The data for individual commodity groups that were used to calculate the TCI were extracted from the UNCTADstat database, which aggregates them in the SITC rev.3 format. 
The calculation of the TCI for the EU and China for the period from 1995 to 2016 revealed a widening gap between the EU's supply in China's demand and China's supply in the EU's demand (Figure 7). While the value of the index calculated for the EU's supply in China's demand reached 52.99 in 1995, its value was 56.59 in 2016. On the other hand, while the value of the index for China's supply in the EU's demand reached 57.35 in 1995, it was only 48.93 in 2016.

Since 2004, the index has been recording a higher overlap annually between the EU's supply and China's demand than between China's supply and the EU's demand. This points to an increasing importance of the EU for China's imports and a relative decline of the importance of China for the EU's imports. The trade complementarity between the two partners reaches a moderate intensity level, which means that the EU and China cannot be regarded as "natural trade partners". However, the medium values of the mutual trade complementarity point to a considerable potential for increased foreign trade as they demonstrate the existence of trade complementarity. Given that the TCI did not reach values close to or exceeding 70 either for the EU or for China, we can rule out the existence of high trade complementarity between these two economies.

However, the EU's global competitiveness does not depend solely on its trade relations with China, which is its second most important trade partner. For this reason, we decided to apply the TCI to the EU's foreign trade with its most important trade partner, the US. The EU has a long-term active trade balance with the US. In 2016, the EU's balance in trade in goods with the US was active at $€ 115.3 \mathrm{bln}$. In trade in services, the EU has also historically recorded trade surpluses with the US with the exception of 2016. In 2015, the EU's surplus in trade in services with the US was $€ 17.9$ bln. In 2016, however, the EU recorded a slight deficit of $€ 1.3 \mathrm{bln}$. Concerning FDI, the US has invested three times more in the EU than in Asia as a whole. The EU has invested eight times more in the US than in India and China combined (European Commission, 2018b).

The EU and the US are becoming increasingly complementary trade partners. The strong trade complementarity of the two economies was confirmed by the results of the TCI, which was calculated for the years from 1995 to 2016 (Figure 8). Over this period, the value of the index did not fall below 70 . While in 1995 the value of the index calculated for the EU's supply in the US demand was 71.09, its value was 77.28 in 2016. The most significant increases for this parameter were recorded from 2012.

Historically the highest overlap between EU supply and US demand was in 2016, when the TCI reached 77.28. The overlap between US supply and EU demand also recorded an increase between 1995 and 2016 as the TCI rose from 70.78 to 76.07. Similarly, historically the highest TCI value was reached in 2016. Between 1996 and 2007, the TCI was higher for US supply and EU demand than for EU supply and US demand. However, 
this trend was reversed in 2008, and by 2016 the index for EU supply and US demand was higher every year than that of US supply and EU demand. This development points to the improving position of the EU relative to the US, which represents an opportunity for the EU to apply its comparative advantages in its trade with the US. On the other hand, the long-term active trade balance of the EU with the US is subject to serious decisions by the US administration, such as stopping the TTIP negotiations or imposing various trade protectionism measures.

\section{Figure 8: Development of trade complementarity between the EU and the US}

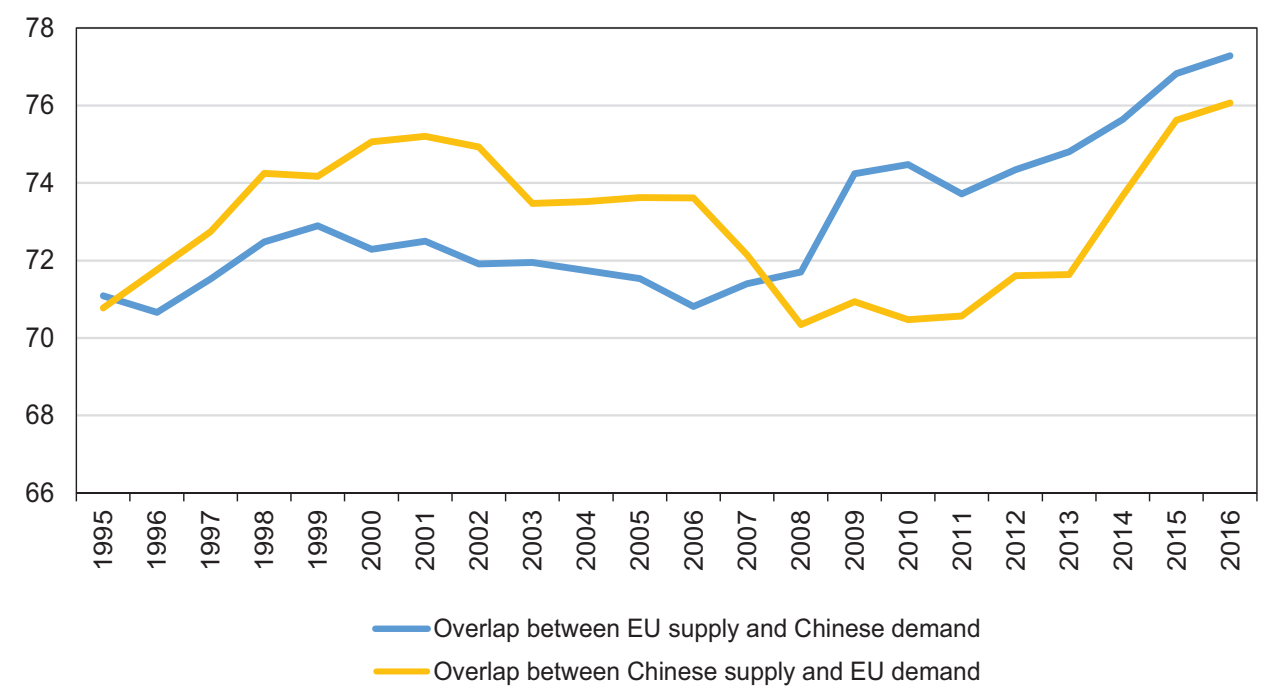

Source: Authors' calculations. The TCI was calculated based on data from UNCTAD, 2018

The TCI revealed the potential for increasing the EU's trade exchanges not only with China but particularly with those trade partners with which the EU achieves a high level of trade complementarity and therefore can be regarded as its "natural trade partners". By increasing the focus of developing trade relations with these countries, the EU members can increase their negotiating position relative to China, namely by reducing their own dependence on China and diversifying their export territories.

An analysis of EU-China foreign trade relations, which was already presented above, highlighted the potential of the service sector. Consequently, we tried to determine the factors contributing to China's persistent trade deficit in this sector and to identify areas of services where European companies could best utilize their know-how and expertise. Finally, the calculations were compared with the estimated regression coefficients and 
real statistical data from China and the US. The regression equation was made using the ordinary least squares method and its form is:

$$
\text { ln_Export_EU5 }=11.94+1.03 * \text { ln_Transport_EU5-0.26*ln_GDP_pc }+0.56 * E U \_m \text {. }
$$

According to the p-value, all the coefficients were estimated with more than $99 \%$ probability. They were also statistically significant based on the F-test (96.91). The R-squared was $85.6 \%$. According to White's test $(\mathrm{P}(\mathrm{Chi}$-square $(8)>13.94)$, there is no heteroskedasticity in our sample. The RESET test showed that the model is correctly built $(\mathrm{F}(2.47)>0.33)$. All these tests indicate that the dependent and independent variables were chosen correctly.

An increase in transportation services exports of the assessed countries by $1 \%$ can result in a $1.03 \%$ increase of total exports of these countries. EU membership is also shown to be a significant determinant of the foreign trade for the assessed countries.

Table 3: Comparison between China and USA

\begin{tabular}{l|c|c}
\hline & China & USA \\
\hline Transport_exp_EU5, million \$ & $5,726.14$ & $22,700.60$ \\
\hline Export_EU5, thousand million \$ & $145,673,189.65$ & $278,411,303.77$ \\
\hline GDP_pc, million \$ & $7,993.07$ & $57,460.87$ \\
\hline Tariff on manufactured goods in \% & 11.02 & 3.78 \\
\hline Population in thousand & $1,403,500.37$ & $325,952.42$ \\
\hline
\end{tabular}

Source: Authors' compilation based on UNCTAD, 2018

Based on empirical findings by Grančay, the positive values of the regression coefficient were expected for GDP per capita. On the other hand, Kittová et al. (2014) argued that the population of assessed countries has a negative impact on mutual trade, which can negatively influence the regression coefficient. Based on the statistical data in Table 3, the above conclusions that the US seems to be a better fit for the EU as a trade partner than China is strengthened. We would like to point out that the removal of trade barriers, which is represented in the model by EU membership, is a significant stimulus for mutual trade. In this regard, China is significantly more protectionist than the US. 


\subsection{The service sector as a key tool for strengthening the EU's competitiveness}

The analysis of the foreign trade relations between the EU and China revealed a considerable potential for developing cooperation between them in the service sector. In the long run, the EU has been experiencing trade deficits with China that result from the EU's lack of competitiveness in its trade in goods. For trade in services, on the contrary, the EU has had long-term trade surpluses. China's current lack of competitiveness in trade in services is evidenced by the fact that it has had a long-term passive balance of its trade in services. Since 2000, China has been able to achieve an active balance in service trade for only four years (2005-2008). In 2016, China recorded its historically highest passive trade balance of services worth $\$ 240.9$ bln (MOFCOM, 2018). It is clear, therefore, that China is still only "catching up" with developed economies in this area of trade, and this creates a considerable market potential for the EU that could be used to strengthen its global competitiveness.

The Chinese government is currently aware that prioritizing the service sector and increasing the added value content of produced goods are key to maintaining China's global competitiveness in the long run (Stuchlíková, 2015). Global perception of China as a "service economy" is also an essential element in ensuring greater confidence in the quality of China's production. Even though the service sector currently has the most significant share of China's GDP creation and employs the largest share of China's labour force, it still does not achieve qualitative parameters that would allow it to be competitive globally.

For most developed countries, the tertiarization processes began in the middle of the $20^{\text {th }}$ century. In that period, China lagged behind economically, and while the developed countries continued to shift their economic focus towards services, China had just begun the process of industrialization that these economies started two centuries earlier, in the middle of the $18^{\text {th }}$ century. The Chinese government started to address the importance of services for China's economy as late as in the late 1970s. The first government document that acknowledged the importance of developing the service sector was the "Decision on Speeding Up the Development of the Tertiary Industry", issued in 1992. This decision triggered significant structural changes in China's economy and the first wave of development of China's service sector, which lasted until China's accession to the WTO in 2001 (Cheng, 2013). The second wave lasted until the start of the global financial crisis at the turn of 2007 and 2008, and the third wave is currently only gaining momentum. The service sector has been given more importance in China's nationwide strategies with the $11^{\text {th }}$ five-year plan. The $12^{\text {th }}$ and the current $13^{\text {th }}$ five-year 
plan regard the service sector as a key component of the Chinese economy (National Development and Reform Commission, 2017).

In 1991, the service sector employed only $25.7 \%$ of China's labour force and significantly lagged behind the world's average, which was 37.3\% (National Bureau of Statistics of China, 2018). However, the share was 49.1\% in 2017, which did not differ significantly from the world's average (World Bank, 2018). In terms of economic output (GDP), the service sector is currently the most important sector of the Chinese economy (National Bureau of Statistics of China, 2018).

\section{Figure 9: Development of China's foreign trade in services (million \$)}

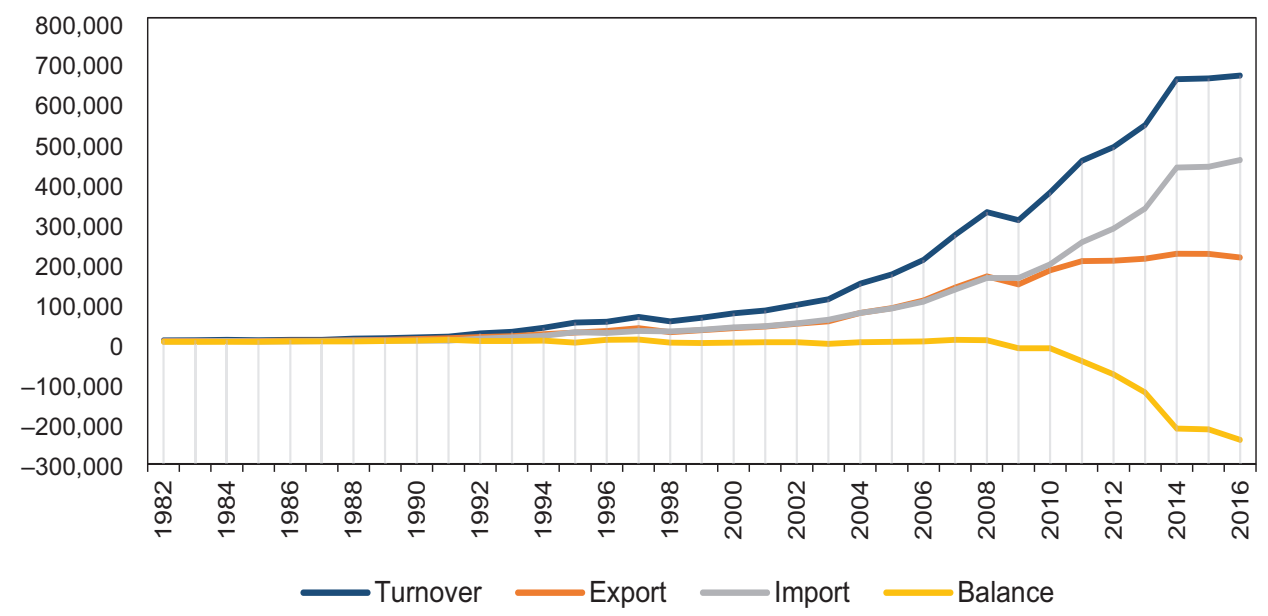

Source: Authors' processing based on data from MOFCOM, 2018

The service sector is an integral part of China's foreign trade. In 1982, China's foreign trade turnover in services reached only $\$ 4,499$ million and China had an active balance of $\$ 769$ million. However, China recorded a passive balance for most of the years. Historically the largest passive balance was recorded in 2016 (\$244.20 bln) (State Administration of Foreign Exchange, 2018). The development of China's foreign trade in services is illustrated in Figures 9 and 10.

The most important categories of services in China's foreign trade from the perspective of China's balance of payments are: travel (tourism), transport, and charges for the use of intellectual property. In all three categories, China records a negative trade balance. These three categories cumulatively contribute to China's passive balance of its trade in services by more than $90 \%$. The development of China's trade in services from the perspective of the country's balance of payments from 2010 to 2016 is illustrated in Table 3. 


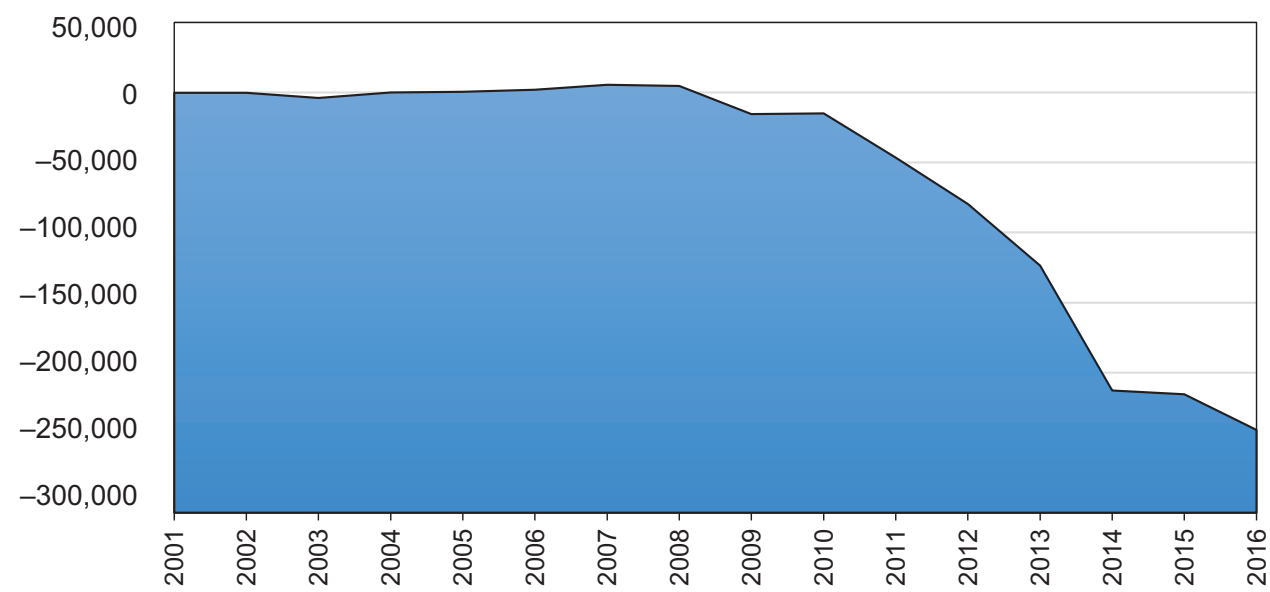

Source: Authors' processing based on data from MOFCOM, 2018

China's balance of payments gives a clear picture of China's foreign trade in services and its international competitiveness. It is clear that China is still lagging behind developed countries in the sophistication of services traded, which is particularly evident in the substantially high negative balances generated by charges for the use of intellectual property, travel and insurance and pension services. The categories of services currently reducing China's negative balance in services are still mainly associated with a lower level of sophistication (such as manufacturing services on physical inputs owned by others, maintenance and repair, and construction services).

The analysis of China's foreign trade in services and its balance of payments reveals a relatively low global competitiveness of the Chinese service sector. This creates significant opportunities for European businesses. Despite the dominant position of the service sector in China's GDP and employment, the country is still lagging behind developed countries and even some developing countries (such as India) in the development of this sector in many qualitative parameters. In 2013, the service sector in China was still dominated by traditional services linked to a relatively low level of sophistication. Its development is limited by the considerable power of state-owned enterprises and also by the fact that many services provided by state-owned enterprises have a limited geographical scope, which consequently leads to loss of efficiency resulting from a lack of competition (Wei, 2013). Even in 2017, China was still a net importer of services (World Bank, 2018). 
Table 3: Development of China's trade in services: balance of payments approach (\$100 million)

\begin{tabular}{|c|c|c|c|c|c|c|c|}
\hline & 2010 & 2011 & 2012 & 2013 & 2014 & 2015 & 2016 \\
\hline Services & -151 & -468 & -797 & $-1,236$ & $-2,137$ & $-2,183$ & $-2,442$ \\
\hline $\begin{array}{l}\text { Manufacturing services on physical } \\
\text { inputs owned by others }\end{array}$ & 251 & 263 & 256 & 232 & 213 & 203 & 184 \\
\hline Maintenance and repair services & 0 & 0 & 0 & 0 & 0 & 23 & 32 \\
\hline Transport & -290 & -449 & -469 & -567 & -579 & -467 & -468 \\
\hline Travel & -91 & -241 & -519 & -769 & $-1,833$ & $-2,049$ & $-2,167$ \\
\hline Construction & 94 & 110 & 86 & 68 & 105 & 65 & 42 \\
\hline Insurance and pension services & -140 & -167 & -173 & -181 & -179 & -38 & -88 \\
\hline Financial services & -1 & 1 & 0 & -5 & -4 & -3 & 11 \\
\hline $\begin{array}{l}\text { Charges for the use of intellectual } \\
\text { property }\end{array}$ & -122 & -140 & -167 & -201 & -219 & -209 & -228 \\
\hline $\begin{array}{l}\text { Telecommunications, computer, and } \\
\text { information services }\end{array}$ & 64 & 89 & 108 & 95 & 94 & 131 & 127 \\
\hline Other business services & 89 & 72 & 87 & 99 & 282 & 189 & 147 \\
\hline $\begin{array}{l}\text { Personal, cultural, and recreational } \\
\text { services }\end{array}$ & -2 & -3 & -4 & -6 & -7 & -12 & -14 \\
\hline Government goods and services & -2 & -3 & -1 & 0 & -10 & -15 & -20 \\
\hline
\end{tabular}

Source: Authors' processing based on data from State Administration of Foreign Exchange, 2018

The prevailing low level of the global competitiveness of China's service sector is also evident from China's increasing trade deficit in services. In 2009, exports of services with a relatively low level of sophistication (e.g., transport or construction services) accounted for around $76 \%$ of China's total service exports. These developments point to China's continued lagging behind developed countries, particularly in services demanding the use of scientific knowledge and sophisticated technologies. A similar problem is faced by FDI directed at the service sector. More than $40 \%$ of all FDI flowing into the sector in China is currently heading for real estate, with modern services accounting for only about $11 \%$. Such a situation does not create sufficient opportunities for further development of the sector that would enable it to reach the sophistication level of developed countries. Wei (2013) points out that if China's service sector is to increase its global competitiveness, broadbased reforms will be needed to overcome the prevailing restrictions and barriers. Chinese economist D. Cheng considers the relatively low level of specialized labour division and 
the persistent high transaction costs in the Chinese economy to also be important factors contributing to the issue (Cheng, 2013).

Despite the ongoing qualitative changes in the sector, currently most commercial services that require close interactions between provider and customer (e.g., marketing or customer services) are under the control of foreign companies (Cheng, 2013). Another problem of this sector in China is its monopolization, which is particularly strong in the financial, transport and telecommunication services. In modern business services, since the beginning of the new millennium, the largest growth has been recorded in telecommunications, computer services, software and scientific research. Their growth is driven mainly by technology and outsourcing. We believe that it is particularly the commercial services that offer significant business opportunities for EU companies.

\section{Conclusion}

The growing interdependence of individual countries and regions that results from globalization puts a pressure on the further strengthening of the EU-China cooperation, in which the EU is struggling to maintain its competitive position. It will be crucial for the future of the EU to find a way to cooperate effectively with China so that it is a mutually beneficial cooperation, which will bring prosperity to both trade partners (Melecký and Staníčková, 2013). The results revealed that China does not regard the EU as a whole as a credible partner. Instead, China regards the EU and its institutions as a platform that concentrates numerous countries of its economic interest in a single access point. China continues to prefer bilateral talks with individual EU member countries over multilateral talks with the EU. This approach allows it to benefit from a better negotiating position, while saving both costs and time. The research also revealed the dominance of a small group of member countries (in both the EU's foreign trade and its volume of FDI inflows in China), which has also confirmed the original assumption that it is short-sighted to analyse the trade flows between the EU and China for the EU as a whole. China's strengthened global position has revealed the factionalism and fragility of mutual relations among members of the EU. In addition to a lack of coordination in dealing with China, it is clear that EU members act in many cases as competitors in the allocation of Chinese investments. This is evidenced, for example, by the rivalry of countries for investments carried out under the OBOR initiative as well as the participation of $11 \mathrm{EU}$ member countries in the 16+1 platform (Garlick, 2015) or the membership of 16 EU member countries in the China-initiated development bank, the AIIB.

The research revealed the existence of a higher trade complementarity between the EU and the US than is the case between the EU and China. This conclusion was 
verified by a regression econometric equation that was inspired by the gravity model. We thus conclude that the intensity of foreign trade increases for countries that are members of the same integration grouping, whereas the volume of transportation services exports also records a significant growth. In this context, along with the recognition of the relatively low trade flows between China and most of the EU member countries, diversification of the trade relations of the EU towards its "natural trade partners" appears to be a rational alternative. If carried out successfully, it could help increase the EU's negotiating position with China. This is a very important finding for both academia and policy makers as China's importance to the foreign trade of EU countries has traditionally been exaggerated.

As for the potential of the service sector, it stems primarily from China's prevailing lack of "global competitiveness" in this sector, which creates considerable market potential for the EU as a whole as well as for its individual member countries. As the EU has recorded a long-term active balance in the bilateral trade in services with China, we believe that an increase in trade with China in this sector may help reduce the EU's continuing trade deficit with China, thereby strengthening the EU's global competitiveness. The focus on trade in services is another major contribution of this paper as this area of foreign trade has been largely unaddressed by both academia and policy makers. The latest developments confirm that in the context of the US protectionist measures, the service sector is the most "immune" to such trade barriers. China has responded very flexibly to the threat from the US and the expansion of its service sector is already well underway.

\section{References}

Baláž, P., Královičová, M. (2017). “One belt, one road” initiative - opportunities, Risks and Consequences for Cooperation of CEE Countries with China. Central and Eastern Europe in the Changing Business Environment: the Proceedings of the $17^{\text {th }}$ International Joint conference. Prague and Bratislava: EKONÓM, pp. 21-31

Baláž, P., Szökeová, S., Zábojník, S. (2012). Čínska ekonomika: nová dimenzia globalizácie svetového hospodárstva. Bratislava: Sprint dva. ISBN 978-80-89393-89-3.

Cheng, D. (2013) The Development of the Service Industry in the Modern Economy: Mechanisms and Implications for China. China Finance and Economic Review, 1(3), 1-12, https://doi.org/10.1186/2196-5633-1-3

Christmann, E. P., Badgett. J. L. (2009). Interpreting Assessment Data: Statistical Techniques You Can Use. Arlington: NSTA Press. ISBN 9781933531366.

Drysdale, P., Garnaut, R. (1982). Trade Intensities and the Analysis of Bilateral Trade Flows in a Many-Country World: A Survey. Hitotsubashi Journal of Economics, 1982(22), 2-84

European Commission (2018a). China. [Retrieved 2018-02-10] Available at: http://ec.europa. eu/trade/policy/countries-and-regions/countries/china/ 
European Commission (2018b). United States. [Retrieved 2017-02-13] Available at: policy/ countries-and-regions/countries/united-states/

Eurostat (2017). [Retrieved 2017-11-24] Available at: http://ec.europa.eu/eurostat

Finger, J. M., Kreinin, M. E. (1979). A Measure of 'Export Similarity' and Its Possible Uses.

The Economic Journal, 89(356), 905-912, https://doi.org/10.2307/2231506

Fojtíková, L. (2017). State Regulation in China in the Light of Its WTO Membership. European Journal of Business Science and Technology, 3(1), 29-43, https://doi.org/10.11118/ejobsat. v3i1.77

Garlick, J. A. (2015). China's Trade with Central and Eastern European EU Members: an Analysis of Eurostat Data, 2004-2014. Acta Oeconomica Pragensia, 23(4), 3-22, https://doi. org/10.18267/j.aop.478

Grančay, M. (2013). Gravitačný model zahraničného obchodu SR s hotovými výrobkami v roku 2011. Almanach: aktuálne otázky svetovej ekonomiky a politiky, 8(1), 21-37.

IMF (2018). World Economic Outlook Update, January 2018. [Retrieved 2018-02-19] Available at: https://www.imf.org/en/Publications/WEO/Issues/2018/01/11/ world-economic-outlook- updatejanuary-2018

Kittová, Z., Baláž, P., Vetrák, M., Mattoš, B., Silná, Z. (2014). Alternatívy vývoja európskej integrácie. Bratislava: EKONÓM. ISBN 978-80-225-3892-3.

Koopman, R., Powers, W., Wang, Z. et al. (2011). Give Credit to Where Credit is due: Tracing Value Added in Global Production Chains. National Bureau of Economic Research. Working Paper No. 16426, pp. 58, https://doi.org/10.3386/w16426

Královičová, M. (2018). Zahraničnoobchodná expanzia Číny a jej dosahy na presadzovanie ekonomických záujmov Európskej únie (na príklade vybraného odvetvia). Dissertation. Bratislava.

Lukáčik, M., Lukáčiková, A., Szomolányi, K. (2011). Ekonometrické modelovanie v programoch EViews a Gretl. Bratislava: EKONÓM. ISBN 978-80-225-3320-1.

Melecký, L., Staníčková, M. (2013). Konkurenceschopnost Evropské unie v procese globalizace světové ekonomiky. Současná Evropa.

MOFCOM (2018). Available at: http://english.mofcom.gov.cn/Article statistic/ BriefStatistics/201712

National Bureau of Statistics of China (2018). [Retrieved 2018-02-20] Available at: http://data. stats. gov.cn/

National Development and Reform Commission (2017). [Retrieved 2018-05-08] Available at: http://en.ndrc. gov.cn/

Pacáková, V. et al. (2009). Štatistické metódy pre ekonómov. Bratislava: IURA Edition. ISBN 978-80-8078-284-9

State Administration of Foreign Exchange (2018). 外汇检查与法规适用. [Retrieved 2018-01-15] Available at: http://www.safe.gov.cn/wps/portal/sy/zcfg_whjcyfgsy 
Stuchlíková, Z. (2015). Čínská ekonomika v roce 2015: hlavní trendy a problémy. Scientia et Societas, 11(3), 37-47.

UNCTAD (2017). World Investment Report 2017. [Retrieved 2017-11-08] Available at: http://unctad.org/en/pages/PublicationWebflyer.aspx?publicationid=1782

UNCTAD (2018). UNCTADstat. [Retrieved 2018-01-04] Available at: http://unctad.org/en/ Pages/statistics.aspx

UNCTAD (2018). UNCTADstat. [Retrieved 2018-12-11] Available at: http://unctadstat. unctad. org/wds/TableViewer/tableView.aspx

Wei, W. (2013). Features, Restrictions, and Policy Recommendations in the Service Sector of the PRC'. Asian Development Bank. ADB Economics Working Paper Series No. 357, https://doi.org/10.2139/ssrn.2295803

WITS (2018). [Retrieved 2018-01-19] Available at: http://wits.worldbank.org/

World Bank (2018). [Retrieved 2018-01-04] Available at: http://databank.worldbank.org/

Zhou, H. et al. (2017). China-EU Relations: Reassessing the China-EU Comprehensive Strategic Partnership. Singapore: Springer. ISBN 978-981-10-1144-3. 